\title{
Assessment of leachates from uncontrolled landfill: Tangier case study
}

\author{
I. ELMAGHNOUGI* $A$. AFILAL TRIBAK ${ }^{*}, M$.MAATOUK ${ }^{1}$
}

Abdelmalek Essaadi university, Science and Technical Faculty, Geology Department, Tangier, Morocco *

*Research Team of Marine Environment and Natural Risks, Faculty of Science and Technical Tangier

${ }^{1}$ Research Team of Geo-Information and Planning, Faculty of Science and Technical Tangier.

\begin{abstract}
Landfill site of Tangier City is non-engineered low lying open dump. It has neither bottom liner nor leachate collection and treatment system. Therefore, all the leachate generated finds its paths into the surrounding environment.

Leachate samples of landfill site were collected and analyzed to estimate its pollution potential. The analyzed samples contained a high concentration of organic and inorganic compounds, beyond the permissible limits.
\end{abstract}

Keywords: Landfill, Leachate, pollution

*Corresponding author: elmaghnougiikram@gmail.com 


\section{Introduction}

Urban waste is one of the major challenges facing our societies. The combination of factors ranging from population growth to urban expansion, to the development of socio-economic and production activities, and to changes in lifestyles and consumption, leads to an increase and waste products

Landfill was originally the technique for the disposal of the most widely used waste in the world, easy to implement and relatively (Saadi et al., 2013). In developing countries, mainly uncontrolled and open pit landfills, where all types of waste (urban, industrial hospital and agricultural) are discarded in mixed. One of the major problems associated with this landfill is the production of liquid effluents rich in organic and mineral matter called leachate or commonly "discharge juice". They come from the percolation of rainwater through the deposits and the contained water in waste and their degradation (Hakkou et al., 2001).

Indeed, as soon as the deposition phase, the waste is subjected to degradation processes linked to complex biological and physico-chemical reactions. Water infiltrates and produces leachates loaded with organic or mineral substances which generate a pollution essentially of organic and inorganic type, in relation with the natural biodegradation of the confined waste. These leachates are a source of contamination of the surrounding environments if they are not collected and processed (Hakkou et al., 2001).

In Morocco, studies carried out by Hamid Chiguer et al in 2016 on the leachates from the Essouira landfill revealed high levels of biodegradable organic matter, heavy metals, minerals and suspended matter. Those of Saadi et al, 2013 on the Oujda dump and Rassam et al, 2012 on the Hoceima landfill showed similar results.

In Algeria, work carried out by Mokhtaria et al in 2007 on the Tiaret landfill showed that leachates contain many organic and metallic contaminants $(\mathrm{Pb}, \mathrm{Zn}, \mathrm{Cd}, \mathrm{Ni}, \mathrm{Cr}+6)$ that exceed the accepted standards. Those of Bennama et al, in 2010 on the El Kerma dump showed similar results.

For this purpose, this study will use the physicochemical analysis methods to characterize the pollutant load of the leachates from the Tangier dump.

\section{Study Area}

\section{Geographic location}

The public dump of Tangier was put into operation in the early 1970s. It stretches over 30 ha $5 \mathrm{~km}$ from the city center on the road to Tetouan. The coordinates of the location are: latitude $35^{\circ} 44^{\prime} 35.32$ "N and longitude $5^{\circ} 45^{\prime} 17.39^{\prime \prime}$.The site belongs to the private domain of the State. It serves the following boroughs: Charf Mghogha, Souani, Tangier Médina and Beni Makada plus waste from industrial zones. 


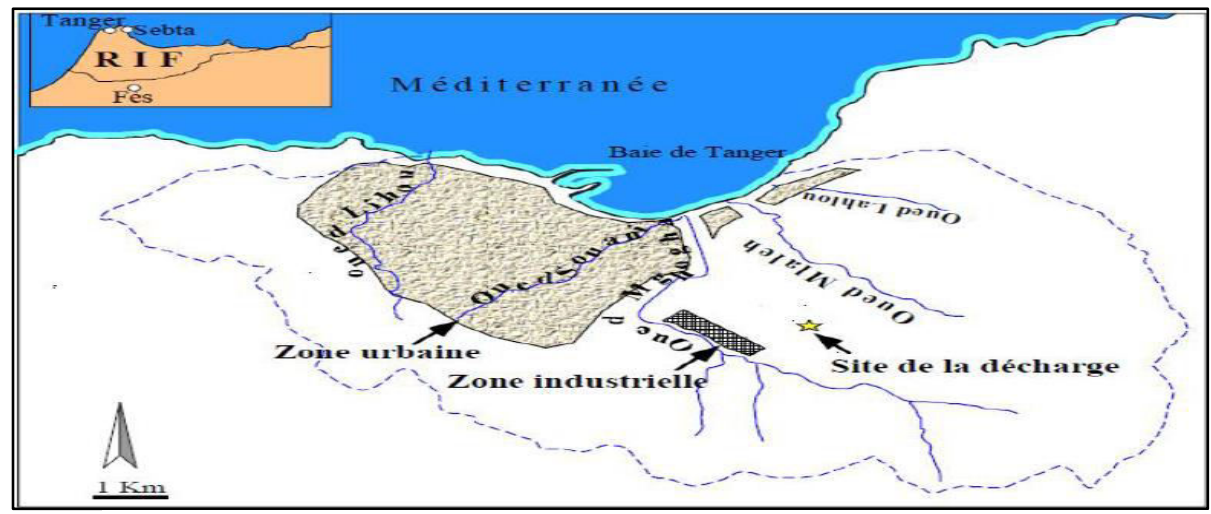

Fig.1. A map showing the location of the existing landfill of Tangier

This landfill is partially fenced and has two premises and a machine for the settlement of waste received daily.

At a distance of $100 \mathrm{~m}$, the landfill is limited to the south by a quarry of clay extraction and by the industrial district about $1 \mathrm{~km}$ to the southwest. To the west of the dump, at a distance of about 200 meters, is a small residential area. To the west of the main entrance to the garbage dump is the shelters of ragpickers, which are built either of metal or wood. The perimeter of the landfill is only fenced to the south, on the other sides, the landfill is bounded by natural obstacles (valley floor to the north, cutting of a slope to the west), so it is easily accessible to the public.

\section{Hydrographic network}

The hydraulic network consists of two wadis around the landfill: Mghogha and M'laleh. The surface water and the leachate flowing over the area of the Tangier landfill flow into the Wadi Ayn At-Taleb Ahmed of Wadi Mghogha, which leads to the bay of Tangier in the immediate vicinity of the residence Sanaa Beach (Figure1).

\section{Field geology}

The unity is characterized by a vast schistous or clayey clay mass of the upper Cretaceous. The hills are surrounded by the Wadi Moghogha and Ghir Boudra valleys in the south and the wadis of Mlaleh and Khandak Bou Hajjar in the east. (GIZ Report, 2006).

\section{Materials and Methods}

Sampling of the leachates were carried out on April 2017, the samples were taken from polyethylene bottles, before the bottles were filled, the samples were washed with the sample to be taken, the bottles were filled edge and then the plugs aims to avoid any gaseous exhaust with the atmosphere. The leachate samples were stored in a cooling apparatus at $4{ }^{\circ} \mathrm{C}$ during transport to the laboratory, they were analyzed immediately.

To avoid the evolution of the samples the conductivity, $\mathrm{PH}$, dissolved oxygen and the temperature were measured in situ using a multi-parameter Brand HACH HQ40d. The physical parameters tested for included:

Color, Conductivity and Temperature. Chemical parameters analyzed were PH, Dissolved oxygen (DO) According to "NM ISO 10523" and ISO 5814 respectively , Nitrate, Nitrite, Chemical Oxygen Demand (COD), Ammonium Ions, Sulfures and Azote were analyzed using Quick method LCK,. HACH LANGE. 


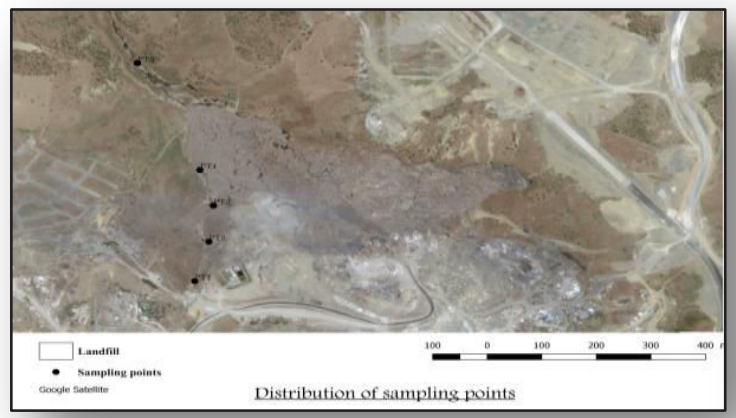

Fig.2. Distribution of sampling points

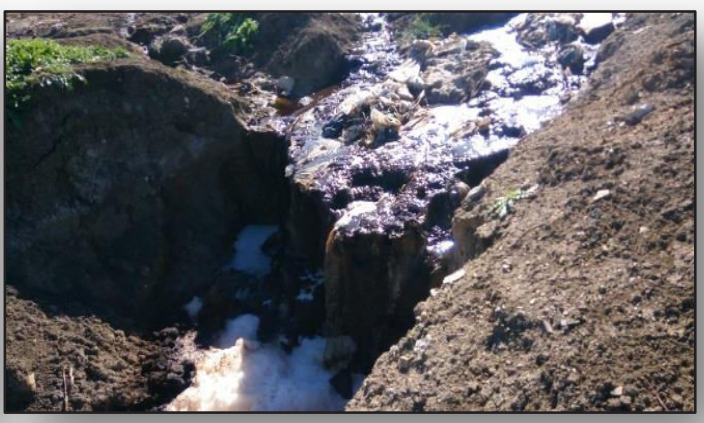

Fig.3. flow of leachate from Tangier discharge

\section{Results and Discussion}

In the landfill, through rainfall, rainwater is loaded with pathogenic germs, organic pollutants and minerals (Ozane, 1990, Martens et al., 1995).

The chemical composition of the leachates is specified at each discharge. Indeed, it varies closely with the nature and age of the landfill, the type of waste, degree of decomposition, method of landfilling, nature of landfill and climatic conditions (Navarro et al 1988, Matejka et al. al. 1994; Khattabi 2002; Aluko et al. 2003; Chofqi et al. 2004; Kurniawan et al. 2006; Renou et al. 2008).

\section{Color and odor}

The leachate from Tangier dump is blackish in color and has a fecal odor. The smell is due

to the presence of organic acids from the decomposition of the highly concentrated organic matter in the waste. The dark color in landfill leachate is also associated with the high concentration of the organic substances (Aziz H.A et al., 2007).

\section{PH}

$\mathrm{PH}$ is an indicator of the different phases of waste degradation. During the various phases of the evolution of a landfill, the $\mathrm{pH}$ values obtained in the leachate could be related to the low concentration of volatile organic compounds. Indeed, during the acid fermentation phase of anaerobic decomposition of waste, young leachates are rich in volatile organic compounds. During this phase, the $\mathrm{pH}$ values are generally lower than 4 (Tchobanoglous et al., 1993). As they age of the landfill, leachate is depleted of volatile organic compounds. This will then cause a rise in $\mathrm{pH}=7$ or above (Kjeldsen et al., 2002). The $\mathrm{pH}$ varied according to the age of landfills (Kulikowska D et al., 2008).Generally, the $\mathrm{pH}$ of a stabilized leachate is higher than that of a young leachate (Poznyak T.G et al., 2008). In general, leachates have $\mathrm{pH}$ between 4.5 and 9 (Christensen T.H et al., 2001). The pH of young leachate is less than 6.5 whereas, $\mathrm{pH}$ of old landfill leachate has $\mathrm{pH}$ higher than 7.5 (Abbas A.A et al., 2009). Initial low $\mathrm{pH}$ is due to high concentration of volatile fatty acids 
(Bohdziewicz J et al., 2008). Stabilized leachate shows fairly constant pH with little variations and it may range between 7.5 and 9 .

The PH values of the leachate vary between 7,81and 8, 3 which is suitable for methanogenic bacteria. Similar results were obtained by El Khamlichi et al. (1997) on the landfill in Rabat (Morocco) and also Trankler et al. who found that leachate samples had a slightly high $\mathrm{pH}$ and remained in the range of 7.0-8.0 during the operations which indicates the short acidic phase and early methanogenic phase. On the other hand, Bahaa-eldin et al. found that the average value of $\mathrm{pH}$ was 6.7 for the municipal landfill leachate in Malaysia indicating the young leachate and the waste degradation was at its late stage of acidic phase.

\section{Conductivity}

The electrical conductivity reflects the mineralization of the sample analyzed. It assesses the overall mineralization and estimates the total water soluble salts, the values of the recorded electrical conductivity fluctuate between $20007-28002 \mu \mathrm{s} / \mathrm{cm}$ ) with a mean value of 22072 This mean value is lower than that recorded in Malaysia discharge $(31.68 \mathrm{lS} / \mathrm{cm})$ (Bahaa-eldin et al., 2010) and also considerably lower than those recorded in the discharge

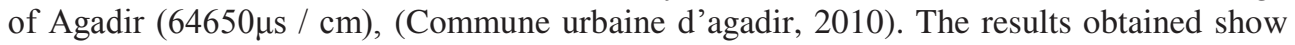
an important mineralization of the leachate of the public dump in the city of Tangier.

\section{Chemical Oxygen Demand COD}

The COD represents the amount of oxygen consumed by the oxidizable materials chemically contained in the water. It is representative of the majority of organic compounds and oxidizable mineral salts (Makhoukh \& al, 2001). In general, young landfill leachate (the acid-phase landfill, <5 years) contain large amounts of biodegradable organic matter. More than $95 \%$ of the dissolved organic carbon (DOC) consists of volatile fatty acids, and some high molecular weight compounds. In mature landfills (the methanogenic-phase landfill), the organic fraction in the leachate becomes dominated by refractory compounds, and the DOC content consists of high molecular weight compounds (Wang F et al.,2003; Wang F et al.,1997).

The high COD values obtained indicate a high organic load; The COD levels recorded in our study range from $1525-9800 \mathrm{mgO} 2 / \mathrm{L}$ they are higher than those reported by (Kouadio \& al,2000) in the Akouedo-Abidjan landfill (between 310 and $2495 \mathrm{mg} / \mathrm{l}$ ) and by (Mekaikia \& al, 2007) in the Tiaret landfill. Algeria $(1048 \mathrm{mg} / \mathrm{l})$, and also by (Commune urbaine d'agadir, 2010) in the Agadir landfill (6220 to $7640 \mathrm{mg} / \mathrm{l}$ ).

On the other hand, they are much lower than those of the Mohammedia landfill (51456 $\mathrm{mg} / \mathrm{l}$ ), and also in Oujda dump (68036mg / 1), and $20468 \mathrm{mg} \mathrm{O} 2 / \mathrm{L}$ at the discharge of Fes (Chtioui $\mathrm{H}$ et al., 2008). This difference could be related to the age, nature and quantity of the waste, as well as the various climatic factors such as rainfall, air humidity and temperature. Indeed, according to (Christensen et al. 2001), these various factors underlie the variability of pollutant loads.

\section{Nitrate}

Nitrates are the final stage of oxidation of nitrogen and represent the form of nitrogen with the highest degree of oxidation in water. The levels recorded ranged from 32,7to 73,1 mg / $\mathrm{L}$ with an average grade of $53.14 \mathrm{mg} / \mathrm{L}$. This value is considerably higher than the maximum concentration allowed by WHO (1980) which is $50 \mathrm{mg} / \mathrm{L}$. Nitrites are derived either from nitrate reduction or incomplete oxidation of ammonium ions (Rodier, 1996). 
The NO2 - leachate levels are low and range from 1,26to 4,24mg / L. These low levels are due to the low values of dissolved oxygen and the redox potential in the leachate.

In the leachate of the public dump in the town of Mohammedia, nitrates reached a concentration of $71 \mathrm{mg} / \mathrm{L}$ (Sabine, 2002). According to (Suabi et al., 2011), the leachate from a waste repository can reach a maximum value of $845 \mathrm{mg} / \mathrm{L}$, High concentrations of nitrates in rivers lead to eutrophication, resulting in a significant development of microorganisms and algae, disrupting natural ecological equilibria (El Kharmouz et al., 2013).

\section{Ions Amonium}

In fact, due to the reducing conditions of the anaerobic reactor, only the reduced forms of nitrogen are encountered very high concentrations of ammonia nitrogen which is one of the delicate problems of leachate treatment.

Observed ammonia concentrations ranged from 875 to $1055 \mathrm{mg} / \mathrm{l}$ with a mean value of $990 \mathrm{mg} / \mathrm{l}$. At this concentration the methanogenic is only slightly inhibited by ammonia, this chemical is the main reducing agent in landfill leachate and is a long-term pollutant (Christensen et al., 2001) lower mean values of ammonia concentrations $(600 \mathrm{mg} / \mathrm{l})$ than those reported in the present study were obtained by Hassan and Ramadan .

\section{Total Kjeldahl Nitrogen and phosphate}

In the present study, it is expected that the mean values of total Kjeldahl nitrogen (1060, 8 $\mathrm{mg} / \mathrm{l})$ and phosphates $(19.19 \mathrm{mg} / \mathrm{l})$ decrease during the stabilization process as found by Hassan and Ramadan (mean values of $973 \mathrm{mg} / \mathrm{l}$ for total nitrogen and $0.33 \mathrm{mg} / \mathrm{l}$ for total phosphate). This may be attributed to the compaction of the wastes in the landfill. In mature leachate ammonia-NH3/total Kjeldahl nitrogen ratio is usually greater than $70 \%$. Which is the case in our study the ratio is about $93 \%$.

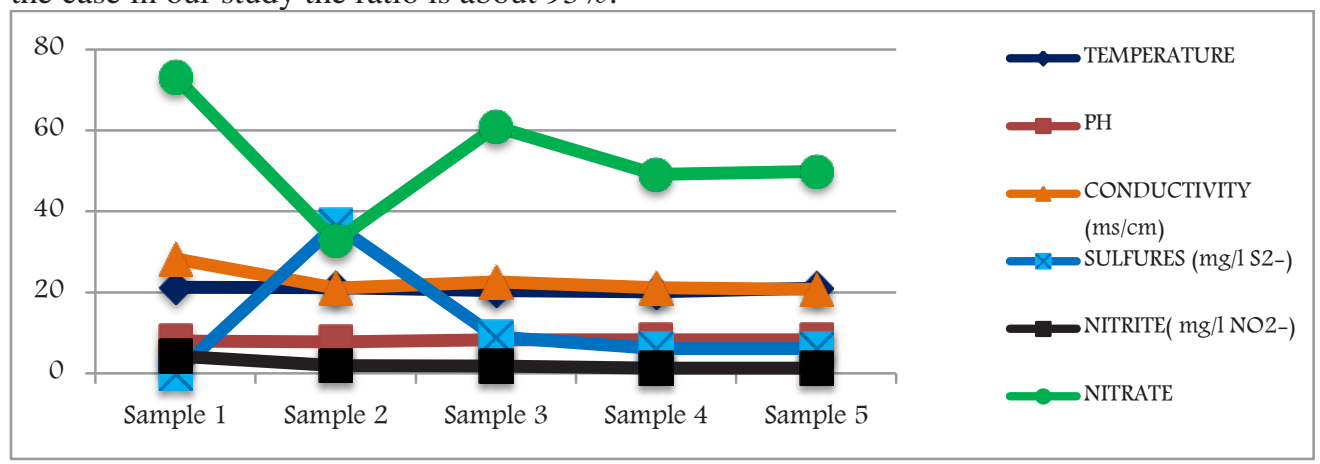




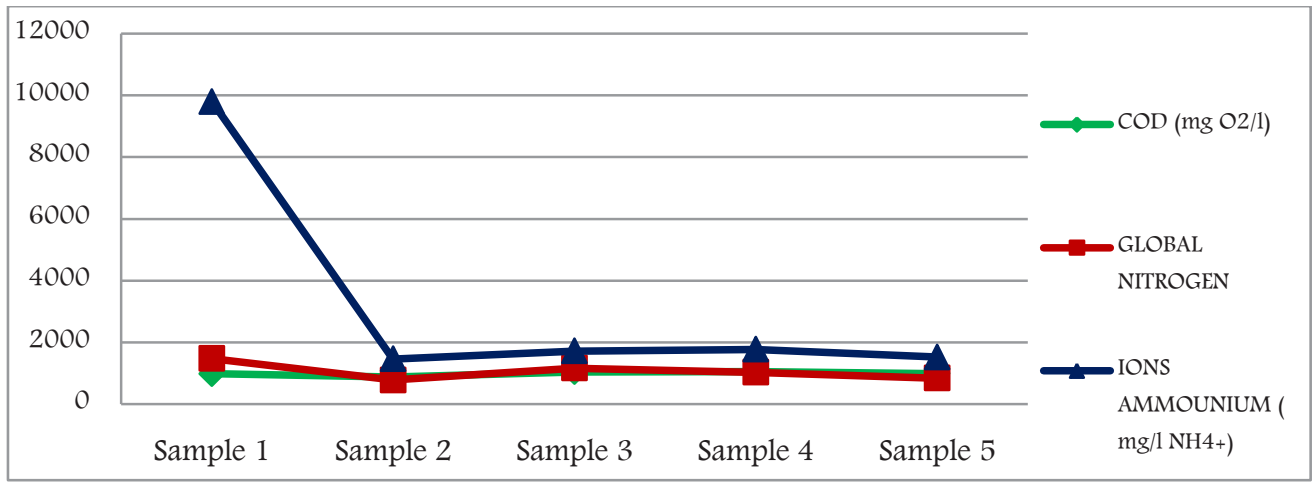

Fig.4. Results of physico-chemical analyzes

Table1. Physicochemical characteristics of leachate from various discharges in the world

\begin{tabular}{|c|c|c|c|c|c|c|c|c|c|c|c|c|c|c|}
\hline $\begin{array}{l}\text { Paramete } \\
\text { rs }\end{array}$ & Unit & $\begin{array}{c}\text { OUJDA } \\
\text { (KHARM } \\
\text { OUZ, } \\
2013 \text { ) }\end{array}$ & $\begin{array}{c}\text { AGA } \\
\text { DIR } \\
\text { (Y. } \\
\text { JIROU } \\
1, \\
2014)\end{array}$ & $\begin{array}{c}\text { KERMA } \\
\text { ALGERI } \\
\text { E } \\
\text { (TAHAR } \\
\text { BENNA } \\
\text { MA, } \\
2011 \text { ) } \\
\end{array}$ & $\begin{array}{c}\text { HOCEI } \\
\text { MA (A. } \\
\text { RASSA } \\
\text { M, } \\
2012)\end{array}$ & $\begin{array}{c}\text { AKOUEDO } \\
\text { (ABIDJAN- } \\
\text { CÔTE } \\
\text { D'IVOIRE)( } \\
\text { A.E. } \\
\text { KOUASSI } \\
\text { ET } \\
\text { AL.2014) }\end{array}$ & $\begin{array}{c}\text { RABAT } \\
\text { (EL } \\
\text { KHAMLI } \\
\text { CHI ET } \\
\text { AL, 2007) }\end{array}$ & $\begin{array}{c}\text { OUJ } \\
\text { DA } \\
\text { (SAA } \\
\text { DI } \\
\text { ET } \\
\text { AL, } \\
2013)\end{array}$ & $\begin{array}{c}\text { SOUIRA } \\
\text { (HAMID } \\
\text { CHIGUE } \\
\text { R1, } \\
2016 \text { ) }\end{array}$ & $\begin{array}{c}\text { FES } \\
\text { (F. } \\
\text { KHA } \\
\text { LIL } \\
\text { ET } \\
\text { AL } \\
, 2015) \\
\end{array}$ & $\begin{array}{r}\text { MOHAME } \\
\text { DIA } \\
\text { (ABDELA } \\
\text { ZIZ } \\
\text { MADINZI, } \\
2014 \text { ) }\end{array}$ & $\begin{array}{c}\text { AGAD } \\
\text { IR } \\
\text { (ELKA } \\
\text { DI ET } \\
\text { AL } \\
2015)\end{array}$ & $\begin{array}{l}\text { TANG } \\
\text { ER } \\
\text { (ELKA } \\
\text { DI ET } \\
\text { AL } \\
2015)\end{array}$ & $\begin{array}{c}\text { ETUEFF } \\
\text { ONT } \\
2009\end{array}$ \\
\hline PH & - & - & 4,3 & 8,19 & 6 & 7,68 & 7,8 & $\begin{array}{c}5,59- \\
6,08\end{array}$ & 8,44 & 7,66 & 8,27 & $7,6-7,9$ & $6,8-7,6$ & 7,69 \\
\hline $\begin{array}{c}\text { Tempera } \\
\text { ture }\end{array}$ & & 17,7 & $\begin{array}{l}19,2- \\
20,8 \\
\end{array}$ & 23,7 & - & 29,8 & - & $\begin{array}{l}14,9- \\
15,7 \\
\end{array}$ & - & - & - & 20,9 & 27,6 & 18,3 \\
\hline $\begin{array}{l}\text { conducti } \\
\text { vity }\end{array}$ & $\begin{array}{c}\mathrm{US} / \mathrm{c} \\
\mathrm{m}\end{array}$ & 170 & 14,6 & 120,3 & 75 & 78,05 & $\begin{array}{c}23,13- \\
74,6\end{array}$ & $\begin{array}{c}4,8- \\
3,7 \\
\end{array}$ & 39,9 & - & - & 58,65 & 33,23 & 30,06 \\
\hline $\mathrm{COD}$ & $\mathrm{mg} / \mathrm{l}$ & - & 72000 & 19333 & 76450 & 1306,25 & $\begin{array}{c}260- \\
50112 \\
\end{array}$ & $\begin{array}{c}68036 \\
- \\
89472 \\
\end{array}$ & 10361 & 5400 & 2473,9 & 38496 & 16810 & 355 \\
\hline BDO5 & $\mathrm{mg} / \mathrm{l}$ & 13520 & 44000 & 3301 & 38200 & 588,08 & 5-10500 & $\begin{array}{c}38188 \\
, 7\end{array}$ & 632 & 1700 & 400,8 & 25395 & $\begin{array}{l}2000- \\
30000\end{array}$ & 36,7 \\
\hline Nitrite & $\mathrm{mg} / \mathrm{l}$ & & 0,125 & 43 & - & 0,69 & - & - & - & - & & - & - & 9,58 \\
\hline Nitrate & $\mathrm{mg} / \mathrm{l}$ & 50 & 62 & 0,93 & - & 92,92 & - & - & - & - & 173,2 & - & - & 126 \\
\hline $\begin{array}{l}\text { Phosphat } \\
\text { es }\end{array}$ & $\mathrm{mg} / \mathrm{l}$ & - & 188,4 & 1,84 & - & 128,74 & - & - & - & - & - & - & - & \\
\hline NH4 & $\mathrm{mg} / \mathrm{l}$ & - & 0,1 & - & - & 388,4 & - & - & - & - & 723 & - & - & 65,4 \\
\hline $\begin{array}{l}\text { Sulfates } \\
\end{array}$ & $\mathrm{mg} / \mathrm{l}$ & - & - & 1717 & - & - & - & - & 0,73 & - & 156,04 & - & & 260 \\
\hline
\end{tabular}

All the results show that besides methanogenesis, is active in the discharge and that this discharge is an old discharge. The basic $\mathrm{pH}$ character of these leachates reflects this phase of biological evolution. The results of leachate analyzes have also shown that percolates are very poor in nitrite. On the other hand, the concentrations of COD, ammonia nitrogen and organic nitrogen (NTK) are relatively high. We can conclude that the leachate from the Tangier landfill is an old leachate, stabilized and characterized by low and difficult biodegradability and a very complex organic load.

\section{Conclusion}

The characterization of the leachates generated by the uncontrolled discharge and open pit of Tangier has shown that it is old and stabilized leachate, conveying a large mineral, organic, metallic pollutant load. These leachates with a high polluting charge risk contaminating the water table under medium permeable bedrock.

\section{References}


- Abbas A.A., Jingsong G., Ping. L. Z., Ya. P. Y., Al-Rekabi. W. S., J. Appl. Review on LandWll Leachate Treatments .Sci. Res. 5(5), 534-545.2009

- Aluko OO, Sridhar MKC, Oluwande PA. Characterization of leachates from a municipal solid waste landfi $l l$ site in Ibadan, Nigeria. J. Environ. Health Res. 2(1):32-37. 2003

- A. Rassam, B. Bourkhiss, A. Chaouch et M. Bourkhiss. Caractérisation des lixiviats et évaluation de la pollution de la décharge de la ville d'al Hoceima / Maroc. Science Lib Editions Mersenne : Volume 4, $\mathrm{N}^{\circ}$ 120602. 2012

- Aziz H.A., Alias S., Adlan M. N., Asaari F. A. H., Zahari M. S. M., Colour removal from landfill leachate by coagulation and flocculation processes, J. Bioresource Technology 98 pp.218-220. 2007

- Bahaa-eldin EAR, Yusoff I, Samsudin AR, Yaacob WZW, Rafek AGM. Deterioration of groundwater quality in the vicinity of an active open-tipping site in West Malaysia. Hydrogeol J 2010; 18:997-1006.

- Bohdziewicz J., Kwarciak A., Landfill leachate treatment by means of anaerobic membrane Desalination. 222(1-3), (2008)

- Chofqi A, Younsi A, Lhadi E, Mania J, Mudry J, Veron A. Environemental impact of an urban landfi ll on a coastal aquifer (El Jadida, Morocco). J. Afr. Earth Sci. 39:509-516. 2004

- Chtioui H., Khalil F., Souabi S., Aboulhassan M. : Evaluation de la pollution générée par les lixiviats de la décharge publique de la ville de Fés. 2008

- Christensen T.H., Kjeldsen P., Bjerg P.L., Jensen D.L., Christensen J.B., Baum A., Albrechtsen H.J., Heron G. Biogéochemistry of landfill leachate plumes, Appl. Geochem., Vol 16, 659- 718. 2001

- COMMUNE URBAINE D'AGADIR ET LABORATOIRE INTERFACE MATERIAUX ENVIRONNEMENT (LIME) DE La Faculté Des Sciences Ain Chock Casablanca, Maroc, Bulletin d'analyse de lixiviat a la décharge contrôlée grand Agadir Maroc. 16-10-2010. 5p.

- El Khamlichi M.A., Lakrabni S., Kabbaj M., Jarby E., Kouhen M. Etude d'impact de la décharge d'Akrach (Rabat, Maroc) sur la qualité des ressources en eau. Revue Marocaine Civil, n68, 17-31. 1997

- EL Kharmouz M, Sbaa M, Chafi A, Saadi S. L'étude de l'impact des lixiviats de l'ancienne décharge publique de la ville d'Oujda (Maroc oriental) sur la qualité physico-chimique des eaux souterraines et superficielles. Larhyss Journal, 16 : 105-119. 2013

- Elkadi Ahmed, Maatouk Mustapha, Tarik Chafik, Raissouni Mohammed. Physicochemical characterization of landfill leachates: a comparison case between Tangier and Agadir (Morocco). J. Mater. Environ. Sci. 6 (11). 2016.

- Emilien Belle. Evolution de l'impact environnemental de lixiviats d'ordures m'ménagères sur les 'eaux superficielles et souterraines, approche hydrobiologies et hydrogéologique. Site d'étude : d'décharge d'Etueffont (Territoire de Belfort-France). Hydrologie. Université de Franche- ' Comté, Français. 2008

- F. Khalil, O. Bouaouine, H. Chtioui1, S. Souabi, M.A. Aboulhassan, A. Ouammou. Traitement des lixiviats de décharge par coagulation-floculation (Treatment of Landfill Leachate by coagulation-flocculation). J. Mater. Environ. Sci. 6 (5). 2015

- HAKKOU R. La décharge publique de Marrakech: caractérisation des lixiviats, étude de leur impact sur les ressources en eau et essai de leur traitement. Thèse de doctorat d'état, université de CAPI AYYAD, Maroc, 150 p. 2001

- Hamid Chiguer, Fatiha E Khayyat, Omar El Rhaouat, Redouane Rifki, Adnane Bensaid, Khadija El Kharrim,And Driss Belghyti. Evaluation of the pollution load of leachates 
from the landfill in the city Essaouira(MOROCCO).International Journal of Innovation and Applied Studies ISSN 2028-9324 Vol. 14. 2016

- Hassan AH, Ramadan MH. Assessment of sanitary landfill leachate characterizations and its impacts on groundwater at Alexandria. J Egypt Public Health Assoc;80:27-49. 2005

- Khattabi H., Intérêts de l'étude des paramètres hydrogéologiques et hydrobiologiques pour la compréhension du fonctionnement de la station de traitement des lixiviats de la décharge d'ordures ménagères d'Etueffont (Belfort, France). Thèse de Doctorat, Université Franche Comté, France, 171p. 2002.

- KJELDSEN P., BARLAZ M.A., ROOKER A.P., BAUM A., LEDIN A., CHRISTENSEN T.A. Present and long-term composition of MSW landfill leachate, Crit. Rev., Environ. Sci. Technol., Vol. 32, n4, 297-336. 2002.

- Kouassi A.E., Ahoussi K.E., Koffi Y.B., Kouame I.K.,Soro N., Biemi J. Caractérisation Physico-Chimique Du Lixiviat D'une Decharge De L'afrique De L'ouest: Cas De La Décharge D'AKOUEDO (ABIDJAN-CÔTE D'IVOIRE).Larhyss Journal, ISSN 11123680, n' 19.2014

- Kulikowska D., Klimiuk E., The effect of landfill age on municipal leachate composition. Bioresour Technol. 99, 5981-5985. 2008

- Kurniawan TA, Lo W, Chan GYS. Physico-chemical treatments for removal of recalcitrant contaminants from landfi ll leachate. J. Hazard. Mater. B129:80-100. 2006

- MAKHOUKH, M., SBAA, M., BERRAHOU, A., VAN CLOUSTER, M. Contribution à l'étude physico-chimique des eaux superficieles de l'Oued Moulouya (Maroc oriental), Larhys journal, ISN 112-3680, ${ }^{\circ}$ 09. pp.149-169. 2001

- Martens P., Bichelle B., Watel M. Wollast A. Audit technique de caractérisation d'une ancienne décharge: composition d'un lixiviat particulier. Techniques, sciences et méthodes l'Eau n6. 1995

- Matejka P., Pollution engendrée par un lixiviat de décharge d'ordures ménagères : bilan hydrique et caractérisation. Environmental Technology, vol.15: $313\llcorner 322.1994$

- MEKAIKIA, M, M; BELABBED, B, E; DJABRI, L; HANI, A; LAOUR, R. Caractéristiques de la décharge publique de la ville de Tiaret et son impact sur la qualité des eaux souterraine. Courrier du Savoir - N08, Juin 2007. pp.93-99. 2007

- Navarro A., Bernard D., Millot N., Les problèmes de pollution par les lixiviats de décharge. Techniques, Sciences et Méthodes-L'Eau 3: 541-545. 1988

- Ozzane, F., Les lixiviats de decharge, les points de connaissance. TSM-Eau, juin 1990. pp.289-312.

- Poznyak T.G., Bautista L., Chairez I.R., Cordova. I., Decomposition of toxic pollutants in landfill leachate by ozone after coagulation treatment .Rios. E., J Hazard Mater. 152, 1108-1114. 2008

- Rapport final de l'étude de faisabilité relatif à l'amélioration de la gestion de la décharge publique de Tanger. Coopération Technique Allemande Programme de Gestion et de Protection de l'Environnement (PGPE).2006

- Renou S, Poulain S, Gagnaire J, Cadarache D, Marrot B, Moulin P. Lixiviat de centre de stockage : déchet généré par des déchets. L'eau, l'industrie, les nuisances, 310:37-43. 2008

- Rodier J. L'Analyse de l'Eau: Eaux Naturelles, Eaux Résiduaires, Eau de Mer: Physicochimie, Bactériologie et Biologie (edn). The Dunod : Paris. 1996

- Saadi S., Sbaa M., El Kharmouz M. Caractérisation physicochimique de lixiviats du centre d'enfouissement technique de la ville d'Oujda (Maroc oriental), Science Lib., Editions Mersenne, Vol. 5, n 130517, ISSN 2111-4706, 1-12. 2013 
- Sabine G., Risques sanitaires liés aux fuites de lixiviats des centres de stockage de déchets ménagers et assimilés. Mémoire de fin d'études, Formation des ingénieurs des génies sanitaires, 19. 2002

- Souabi S., Touzare K., Digua K., Chtioui H., Khalil. F., et Tahiri M. Triage et valorisation des déchets solides à la décharge publique de la ville de Mohammedia. Les technologies de laboratoire, 6 121-130. 2011

- Tahar Bennama, Abdelkader Younsi, Zoubir Derriche et Abdelkader Debab. Characterization and physico-chemical treatment of El-Kerma (Algeria) landfi $l l$ leachates by batch adsorption on untreated and chemically activated sawdust. Water Qual. Res. J. Can. · Volume 45, No. 1, 81-90.2010

- TCHOBANOGLOUS G., THEISEN H.,VIGIL S. Integrated Solid Waste Management, McGraw-Hill International Edition, New York, 978 p.1993

- Trankler J, Visvanathan C, Kuruparan P, Tubtimthai O. Influence of tropical seasonal variations on landfill leachate characteristics — results from lysimeter studies. Waste Manage; 25:1013-20. 2005

- Wang F., Smith D.W., El-Din M.G., Application of advanced oxidation methods for landfill leachate treatment-a review .J. Environ. Eng. Sci. 2) 413-427. 2003

- Welander U., Henryson T., Welander T., Nitrification of landfill leachate using suspended-carrier biofilm technology.Water. RES. 31 2351-2355. 1997

- Y. JIROU, M.C. HARROUNI, M. BELATTAR, M. FATMI1 \& S. DAOUD. Traitement des lixiviats de la décharge contrôlée du Grand Agadir par aération intensive. Rev. Mar. Sci. Agron. Vét. 2 (2):59-69.2001 